\title{
Unusual Clinical Manifestations of Chronic Discoid Lupus Erythematosus
}

\author{
Ljubka MITEVA ${ }^{1}$, Valentina BROSHTILOVA ${ }^{1}$, Robert A. SCHWARTZ2 \\ ${ }^{1}$ Department of Dermatology and Venereology, Medical University, 1431 Sofia, Bulgaria \\ ${ }^{2}$ Dermatology and Pathology, Rutgers University New Jersey, Medical School, Newark \\ *Correspondence: Ljubka Miteva, E-mail: lubka_miteva@abv.bg
}

UDC 616.5-004:618.1]-085

UDC 616.5-004:616.64]-085

\section{DE GRUYTER OPEN}

\begin{abstract}
A 22-year-old woman with a 3-year history of discoid lupus erythematosus presented with two circumscribed patches of non-scarring alopecia, clinically simulating alopecia areata. Histopathological analysis of scalp lesions revealed discoid lupus erythematosus. Based on the clinical history, physical examination, and histological and immunological findings, we distinguished our case from a true combination of alopecia areata and typical chronic discoid lupus erythematosus.
\end{abstract}

\section{Key words}

Lupus Erythematosus, Discoid; Alopecia Areata; Comorbidity

$\mathrm{T}$ ypical manifestations of chronic discoid lupus erythematosus (CDLE) of the scalp have been well described (1, 2). Any discrepancy warrants investigation. Other disorders, including alopecia neoplastica (cutaneous metastatic disease of the scalp) and alopecia areata, may require distinction $(2,3)$. We report a patient with CDLE clinically resembling alopecia areata.

\section{Case report}

A 22-year-old Caucasian woman was first seen with a 3 -year history of gradually developing asymptomatic erythematous plaques located on her face and upper arms, associated with reversible patchy hair loss that appeared periodically, and had a self-limiting course. There was no history of an associated disorder and intake of medications. The possibility of drugrelated hair loss and common causes of hair loss, such as androgenic alopecia, were excluded. Topical corticosteroid ointments were applied in short-term regimens.

Clinical examination revealed oval scaly erythematous plaques varying in size, from 2 to $3 \mathrm{~cm}$, localized on the face, upper arms and the shoulder region. The plaques were well demarcated with peripheral spreading. Two round-to-oval denuded slightly erythematous patches with white hair regrowth were seen in the frontal scalp (Figure 1). Signs of atrophy were not detected. Oral and genital mucosa, were not involved.

\section{Laboratory findings}

The patient's complete blood count, erythrocyte sedimentation rate, C-reactive protein, urea, electrolytes, liver function tests, thyroid function, lipid profile, blood glucose and serum immunoglobulins were all normal. Antinuclear, anti-smooth muscle, SS-A antibodies were negative.

\section{Histopathological analysis}

Biopsy specimens from the scalp and arm revealed identical changes (Figure 2). Follicular hyperkeratosis and dense lymphocytic lichenoid infiltrates obscured the dermo-epidermal junction. Perifollicular and periadnexal lymphocytic infiltrations were present in the reticular dermis. 


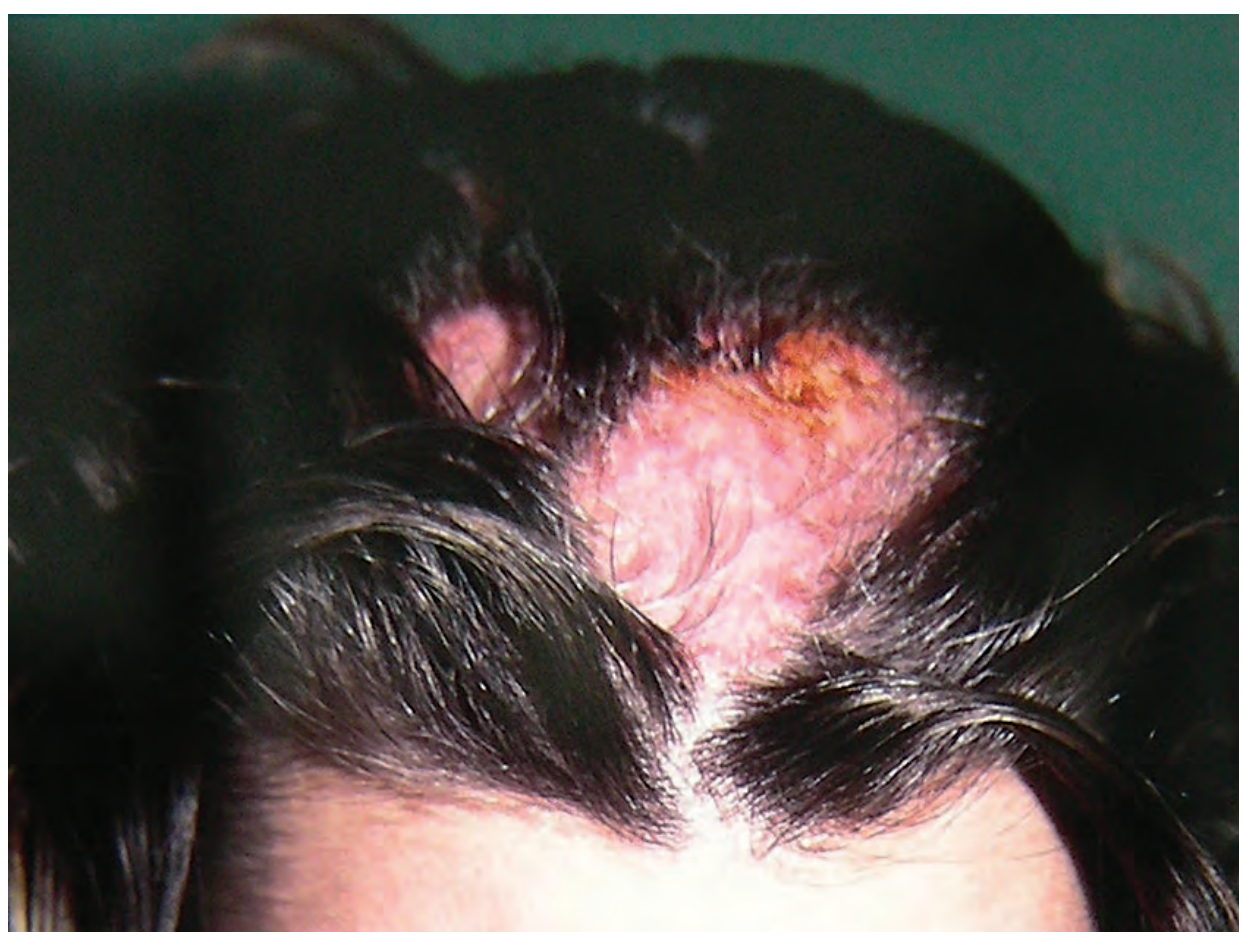

Figure 1. Two patches of circular, non-scarring alopecia on the scalp and a discoid plaque on the face

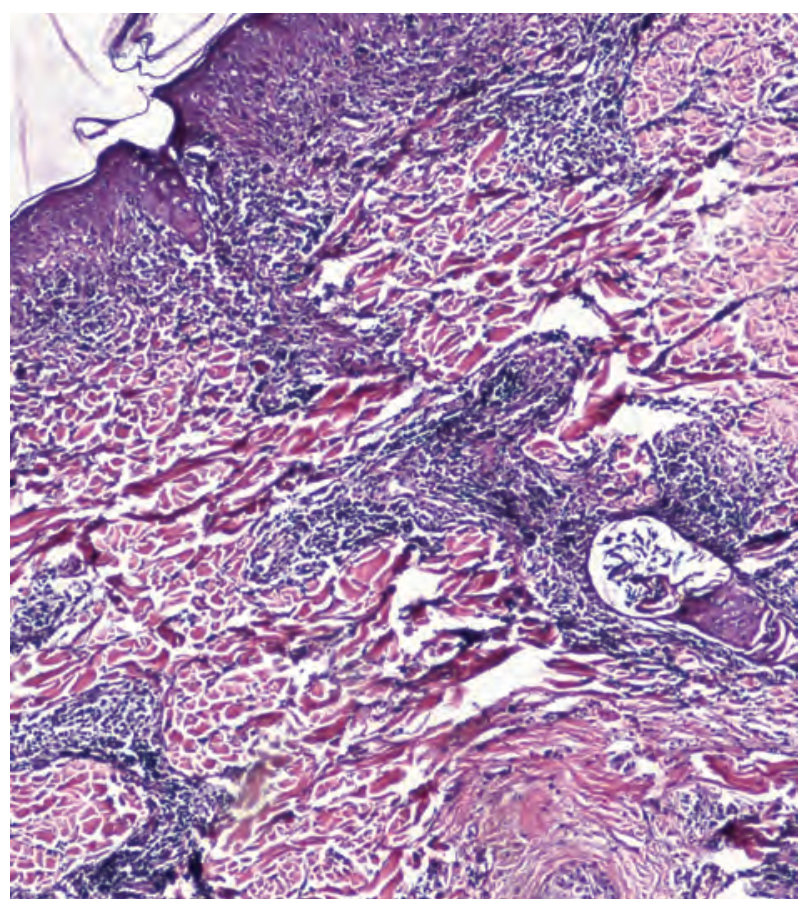

Figure 2. Follicular hyperkeratosis, vacuolar degeneration of the basal layer with obscured dermo-epidermal junction, lichenoid infiltration of the papillary dermis and dense perifollicular lymphocytic infiltrate in the deep dermis (hematoxylin and eosin, $\mathrm{x} 400$ ).
Direct immunofluorescence of the scalp specimen and the plaque on the arm showed granular IgM, IgG and C3 deposits extending in a linear distribution along the dermo-epidermal junction.

\section{Therapy}

Chloroquine phosphate (250 $\mathrm{mg}$ daily) and a potent topical steroid ointment (twice daily) were initiated. At the 3-week follow-up visit, a significant improvement was observed. The cutaneous lesions resolved and alopecia plaques reduced in size. Stronger hair regrowth was evident.

\section{Discussion}

Clinical manifestations of chronic discoid lupus erythematosus (CDLE) are well recognized (4). Our case is interesting due to its unusual presentation. Most of the morphological signs of CDLE matched classical description. However, there were circumscribed patches of non-scarring alopecia on the scalp, closely resembling alopecia areata. Development of alopecia areata-like patches in patients with CDLE is distinctly unusual.

A characteristic cutaneous feature of CDLE of the scalp is scarring alopecia. Scalp involvement 
occurs in $60 \%$ of CDLE patients and it is the only area involved in approximately $10 \%$ (5). Association of alopecia areata (AA) and CDLE has been reported anecdotally (6). In a cohort study of 736 AA patients, two had CDLE (7): two autoimmune disorders occurring together. More recent studies, performed by Kumar et al. (8), and Grandoflo et al. (9) also demonstrated a low incidence of CDLE in patients with AA, with only one of 104 patients affected and one of 68 , respectively.

Systemic lupus erythematosus and lupus panniculitis may also induce non-scarring alopecia resembling AA $(10,11)$. A 27-year-old woman was described with a previous history of lupus erythematosus having slightly erythematous circumscribed patches of non-scarring alopecia closely simulating AA (11). The clinical history of scalp tenderness and histologic findings of predominantly subcutaneous and deep dermal lymphocytic infiltrates surrounding deep follicular segments and hair bulbs, as well as eccrine glands, were consistent with the diagnosis of lupus panniculitis and ruled out a true combination of AA and CDLE. Presumably, temporary hair loss, clinically simulating AA, was due to deeper lymphocytic inflammation that spared the hair bulbs and permanent stem cell-rich follicular segments $(11,12)$.

Based on the clinical and immunological findings, as well as histological changes observed in our patient, consisting of epidermal involvement with prominent vacuolar degeneration, upper dermis invasion by heavy, hugging type lymphocytic infiltrates and deep periadnexal inflammation, with granular IgM, IgG and C3 deposits extending in a linear distribution along the dermo-epidermal junction on direct immunofluorescence of the scalp specimen and the plaque on the arm, we believe she had true CDLE with hair involvement clinically resembling AA.

\section{Conclusion}

We report a patient with chronic discoid lupus erythematosus clinically resembling alopecia areata. In order to establish the diagnosis of scarring alopecia, scalp specimens should be divided into two vertical sections: one is used for direct immunofluorescence, the other for light microscopy.

\section{References}

1. Faezi ST, Hosseini Almodarresi M, Akbarian M, Gharibdoost F, Akhlaghi M, Jamshidi A, et al. Clinical and immunological pattern of systemic lupus erythematosus in men in a cohort of 2355 patients. Int J Rheum Dis 2014;17:394-9.

2. Wollina U, Hein G. Lupus erythematosus: uncommon presentations. Clin Dermatol 2005;23:470-9.

3. Schwartz RA. Cutaneous metastatic disease. J Am Acad Dermatol 1995;33:161-82.

4. Gilliam JN. Immunopathology and pathogenesis of cutaneous lupus erythematosus. In: Safai B, Good RA, editors. Immunodermatology. New York: Plenum Publishing Corporation; 1981. p. 323-32.

5. Patel P, Werth V. Cutaneous lupus erythematosus: a review. Dermatol Clin 2002; 20:373-85.

6. Shimaoka Y, Hatamochi A, Hamasaki Y, Suzuki H, Ikeda H, Yamazaki S. Discoid lupus erythematosus exacerbated by contact dermatitis caused by use of squaric acid dibutylester for topical immunotherapy in a patient with alopecia areata. J Dermatol 2008;35:151-3.

7. Muller SA, Winkelmann RK. Alopecia areata. Arch Dermatol 1963;88:290-7.

8. Kumar B, Sharma VK, Sehgal S. Antismooth muscle and antiparietal antibodies in Indians with alopecia areata. Int J Dermatol 1995;34:542-5.

9. Grandolfo M, Biscazzi AM, Pipoli M. Alopecia areata and autoimmunity. G Ital Dermatol Venereol 2008;143:277-81.

10. Yun SJ, Lee JW, Yoon HJ, Lee SS, Kim SY, Lee JB, et al. Cross-sectional study of hair loss patterns in 122 Korean systemic lupus erythematosus patients: a frequent finding of non-scarring patch alopecia. J Dermatol 2007;34:451-5.

11. Kossard S. Lupus panniculitis simulating alopecia areata. Australas J Dermatol 2002;43:221-3.

12. Parodi A, Cozzani E. Hair loss in autoimmune systemic diseases. G Ital Dermatol Venereol 2014;149:79-81.

\section{Atipične kliničke manifestacije hroničnog diskoidnog eritemskog lupusa}

\section{Sažetak}

Uvod. Poznato je da se u hroničnom diskoidnom eritemskom lupusu mogu videti klinički tipične promene kako na koži lica, trupa i ekstremiteta, tako i u kosmatom delu glave. U diferencijalnoj dijagnozi alopecičnih promena, naročito u nekarakterističnim slučajevima, uprvom redu treba isključiti neoplazijsku 
alopeciju (metastacka bolest kože poglavine) i alopeciju areatu.

Prikaz slučaja. U radu autori prikazuju slučaj dvadesetdvogodišnje osobe ženskog pola ,koja u svojoj anamnezi navodi da tri godine boluje od diskoidnog eritemskog lupusa. Na pregledu osim tipičnih promena na kože trupa, na koži kosmatog dela glave uočene su dva cirkumskriptna alopecična polja na kojima se nisu uočavali znaci atrofije ili ožiljavanja. Histopatološka i direktna imunofluorescentna analiza isečaka kože uzete sa promene na trupu i sa kože alopecičnog plaka na poglavini pokazale su identične promene, karakteristične za diskoidni eritemski lupus.

Zaključak: Autori prikazuju slučaj hroničnog diskoidnog lupusa na koži poglavine koji je klinički imponovao na alopeciju areatu.

U cilju dijagnostikovanja ožiljne alopecije, bioptat kože uzet sa kože skalpa uvek treba podeliti na dva vertikalna dela: jedan pripremiti za svetlosnu mikroskopsku analizu, a drugi za derektni imunofluorescentni pregled.

\section{Ključne reči}

Diskoidni eritemski lupus; Alopecia areata; Komorbiditet 